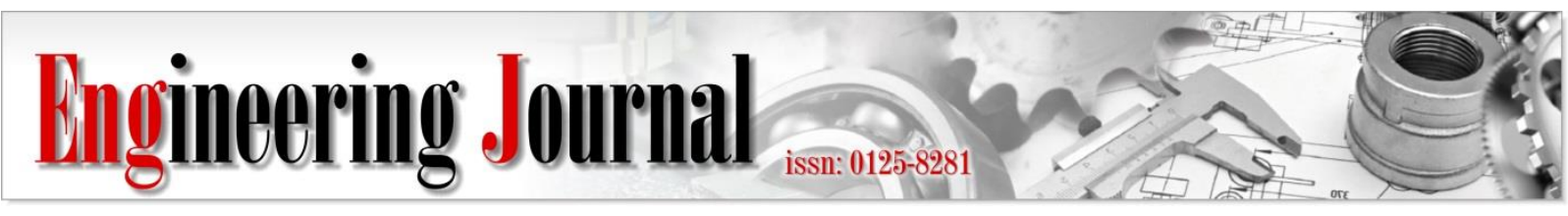

Article

\title{
Influence of Feedstock Particle Size from Merbau Wood (Intsia bijuga) on Bio-Oil Production Using a Heat Pipe Fin L-Shaped Condenser in a Pyrolysis Process
}

\author{
Nasruddin A. Abdullah ${ }^{1,2, a}$, Jordy Tila ${ }^{1}$, Imansyah Ibnu Hakim ${ }^{1}$, Raldi A. Koestoer ${ }^{1}$, \\ and Nandy Putra ${ }^{1, b}$ \\ 1 Heat Transfer Laboratory, Department of Mechanical Engineering Universitas Indonesia, Kampus UI \\ Depok 16424, Indonesia \\ 2 Department of Mechanical Engineering, Faculty of Engineering Universitas Samudra, Kota Langsa, \\ 24416, Indonesia \\ E-mail: anasruddin@unsam.ac.id, bnandyputra@eng.ui.ac.id (Corresponding author)
}

\begin{abstract}
Bio-oil (liquid smoke) can be produced by condensing pyrolysis vapor. As a raw material, the sawdust from Merbau wood (Intsia bijuga) is heated to generate vapor. These vapors are then condensed in a liquid collecting system (LCS). The particle size of the sawdust influences the heating rate and eventually affects bio-oil production. To increase the yield of bio-oil while decreasing the power consumption of the process, the LCS design must be improved. In the present study, the authors aim to understand the relationship between the particle size and the liquid smoke yield using an LCS equipped with L-shaped heat pipe fin condensers. To this end, we experimentally investigated the influence of the particle size $(2 \mathrm{~mm}, 0.707 \mathrm{~mm}$, and $0.595 \mathrm{~mm})$ of the raw material on the liquid smoke yield of an LCS in a pyrolysis process. The results show that increasing the feedstock particle size of Merbau wood sawdust increases the yield of liquid smoke. With a particle size of $2 \mathrm{~mm}$, we achieved a $6 \%$ higher yield of liquid smoke than that with a particle size of $0.595 \mathrm{~mm}$. In addition, the installation of the L-shaped heat pipe fin condensers improved the LCS performance.
\end{abstract}

Keywords: Particle size, Merbau wood, liquid collecting system, heat pipe fin L shaped, liquid yield.

ENGINEERING JOURNAL Volume 24 Issue 4

Received 5 December 2019

Accepted 21 April 2020

Published 31 July 2020

Online at https://engj.org/

DOI:10.4186/ej.2020.24.4.261 


\section{Introduction}

Biomass resources are abundant worldwide. Biomass feedstock can originate from agricultural residues, municipal solid waste, wood waste, forest residues, energy crops, and animal manure. In Indonesia, Merbau wood (Intsia bijuga) is among plant species that are available abundantly. Generally, Merbau sawdust is used in cooking by incinerating it, but this process produces harmful substances, such as carbon monoxide, owing to the imperfect combustion. Such substances can be harmful, and even fatal, to humans. The generation of these byproducts can be avoided using an appropriate recycling method. To this end, pyrolysis is considered the most appropriate and simplest method. Sawdust is used as a feedstock material for pyrolysis given its widespread availability, as well as considering the viewpoint of waste utilization $[1,2]$.

Liquid smoke, also called bio-oil, is a substance produced from biomass, which can be used as a preservative and as a fuel for power plants and transportation, as well as in other chemical products such as resins, insecticides, agricultural materials, and fertilizers. Liquid smoke is used as a preservative for foodstuffs such as meat and fish, and its other antibacterial activities have been exploited widely and commercially [3, 4]. Liquid smoke obtained from fast pyrolysis can be utilized as a combustible fluid in industrial boilers/furnaces [5]. This product can be considered a source of useful chemicals [6]. Moreover, it can be purified to fuel [7]. Liquid smoke can be used as a wood preservative, either by itself or in combination with other preservatives [8], and it is obtained by condensing the vapors generated during the pyrolysis of wood, followed by the removal of carcinogenic polyaromatic hydrocarbons. The main products of wood pyrolysis are liquid fumes of phenols, carbonyls, and organic acids, substances that can provide flavor, color, and antimicrobial properties [9].

Abdullah et al. used a double pipe for pyrolyzing sawdust to achieve the maximum pyrolysis temperature and to investigate the effects of temperature distribution and heating rate from the viewpoint of generating the maximum fluid yields in the cases of using/not using wall temperature control. They obtained a maximum liquid yield of $32.2 \mathrm{wt} . \%$ at a pyrolysis temperature of $500^{\circ} \mathrm{C}$, a cooling water temperature of $15^{\circ} \mathrm{C}$, and a heating rate of $44.43^{\circ} \mathrm{C} / \mathrm{min}$. The maximum liquid yield was $30.50 \mathrm{wt} . \%$ for an uncontrolled reaction temperature (without a proportional-integral-derivative (PID) controller), and the process occurred with a maximum heat supply of $1,000 \mathrm{~W}$, a heating switch at $500^{\circ} \mathrm{C}$, and a heating rate of $7.34^{\circ} \mathrm{C} / \mathrm{min}$; the temperature of the cooling water was the same as the ambient temperature [10].

J. Guan et al. researched granular biomass, and their results showed that the particle size affects the pyrolysis duration: the smaller the particle size, the shorter the time required to burn the raw materials to the core, and vice versa [11]. The particle size influences the process of pyrolysis employed to produce liquid smoke [12]. Suitable particle sizes can minimize the heat transfer problem in pyrolysis [13].

Researchers working on the vapor condensation process have focused on the liquid collection system (LCS) performance improvement. Heat exchangers are widely used for condensing liquid smoke because their use makes it easy to control the cooling temperature. LCS researchers are now focusing on fractional condensation in pyrolysis to extract the desired products [14]. In transforming the vapor phase into the liquid phase, the heat transfer rate can be improved using a suitable condenser [15]. High liquid yield has been achieved using a direct contact condenser [16]. The product yields are not significantly different when using cold water and ambient-temperature water (regular water) as the cooling fluid in the condenser [17]. The presence of a vapor chamber in the system increases the heating rate and enhances cooling performance [18]. The liquid yield increases due to an increase of the vapor temperature up to $200{ }^{\circ} \mathrm{C}$; this process was obtained in a fixed bed reactor at a low heating rate [19].

Heat pipes are a heat transfer device that can transfer heat and energy. When used for heat transfer in the pyrolysis process, heat pipes perform the function of passive cooling. Typically, a heat pipe is a hollow cylindrical pipe filled with a volatile liquid. The heat pipe itself is divided into evaporator and condenser parts. In the evaporator section, heat is absorbed by the surface of the heat pipes. This heat evaporates the liquid in the heat pipe. The evaporated liquid moves toward the condenser section, and it discharges heat into the environment through the surface of the heat pipes in the condenser. Steam is condensed, and the liquid falls into the evaporator under the effect of gravity. This process indicates that the heat pipe does not use electrical energy because it uses the temperature difference with respect to the surrounding environment to release heat. In the experiment conducted herein, we used a heat pipe equipped with fins to accelerate heat release from the heat pipe [20].

During presently, researchers have focused on studying pyrolysis reactors [21]. A cyclone separator, which is an electrostatic precipitator, has been used for pyrolysis [22]. Several researchers have sought to improve the existing condensation system used for pyrolysis to understand the characteristics of the bio-oil produced in the process. Several other researchers have studied the geometry of biomass at various process stages, starting from before pyrolysis until the end of pyrolysis [11]. However, the influence of the heat pipe fin condensers on the liquid yield of pyrolysis has not been studied thus far. Therefore, we focused on designing a heat pipe fin-based condenser and on examining the liquid yield obtained with different particle sizes. The objective of the present research was to determine the influence of the particle size and vapor heater on the liquid yield using L-shaped heat pipe fin condensers. 


\section{Materials and Methods}

\subsection{Materials}

The feedstock material was waste Merbau wood (Intsia bijuga) sawdust from furniture units. This wood is used to fabricate floorboards and wall furniture.

The heating rate of biomass is the primary factor influencing the liquid yield in pyrolysis [23]. Different particle sizes can lead to different heating rates and input energy requirements [24]. We subjected Merbau wood to thermogravimetric analysis (TGA) and differential thermal analysis (DTA) to investigate its thermal degradation and measure its thermal conductivity and heat capacity.

The shell construction of the proposed LCS condenser with L-shaped heat pipe fins is made of SS304 pipes, Sch 10, three-inch diameter, and $660 \mathrm{~mm}$ length. This condenser is equipped with two JIS $10 \mathrm{~K}$ flanges of threeinch diameter to connect the pyrolysis vapor input and the output liquid product. We fabricated two types of condensers: a condenser with heat pipes and a condenser without heat pipes. Both condensers were using the same material. L-shaped heat pipe fins made of copper, measuring $110 \times 140 \mathrm{~mm}$, with a cross-sectional area of $5 \times 6.5 \mathrm{~mm}$, were installed on these condensers. In addition, the heat pipe was equipped with 52 fins of size $21 \times 16.5 \times 1 \mathrm{~mm}$ with an inter fin spacing of $1.52 \mathrm{~mm}$. A detailed drawing of the L-shaped heat pipe fins is shown in Fig. 1.

\subsection{Methods}

The first step in our experiment was feedstock preparation. The material was crushed into small pieces using a blender/liquidizer. Then, the small pieces of wood were sieved into mesh $30(0.595 \mathrm{~mm}), 25(0.707 \mathrm{~mm})$, and mesh 10 (2 mm). Subsequently, the pieces were dried by using a vacuum drying oven. The thermal conductivity of the feedstock was measured, and its heat capacity was calculated by performing TGA and DTA analyses.

A laboratory-scale tubular fixed-bed reactor was fabricated from SUS 316L. The reactor was connected to an electric heater, which was installed in the system. Electric power was supplied to the reactor at a constant level of $1,500 \mathrm{~W}$, and a PID controller was connected to the heater system to control the decomposition temperature in the pyrolysis process by controlling the wall temperature at $500^{\circ} \mathrm{C}$. The reactor's volume was $1,065 \mathrm{~cm}^{3}$. A voltage regulator was installed to control the heating rate of the process. Calcium silicate was used for heat insulation in the reactor to reduce heat loss from the reactor. Condensation occurred when a hot vapor flowed from the reaction zone into the heat pipe fin condenser in the LCS. The vapor produced by pyrolysis was exposed to the heat pipes, where it condensed naturally into a liquid phase.

An electric heater was mounted in the reaction zone to control the vapor temperature, and this heater was

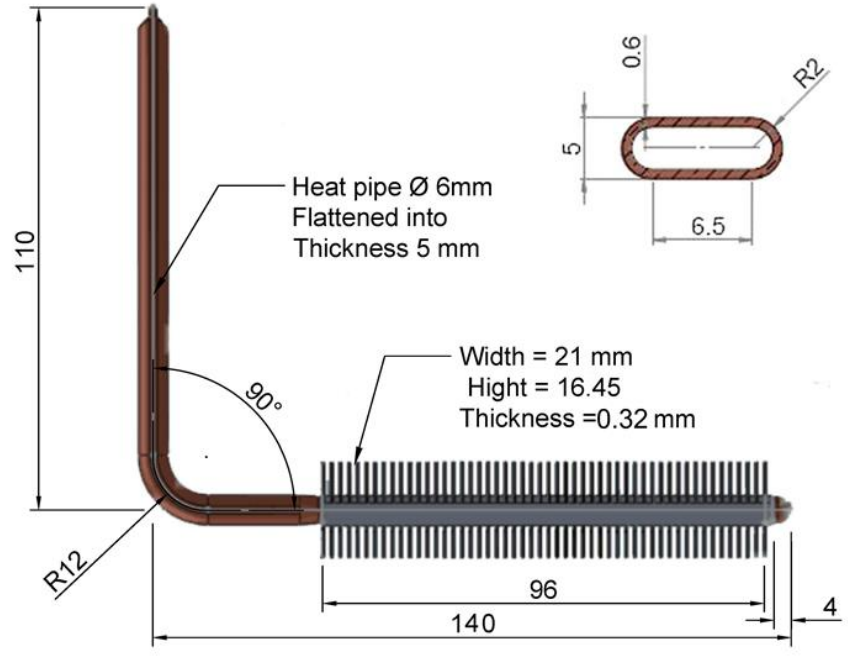

Fig. 1. Detailed drawing of an L-shaped heat pipe fin.

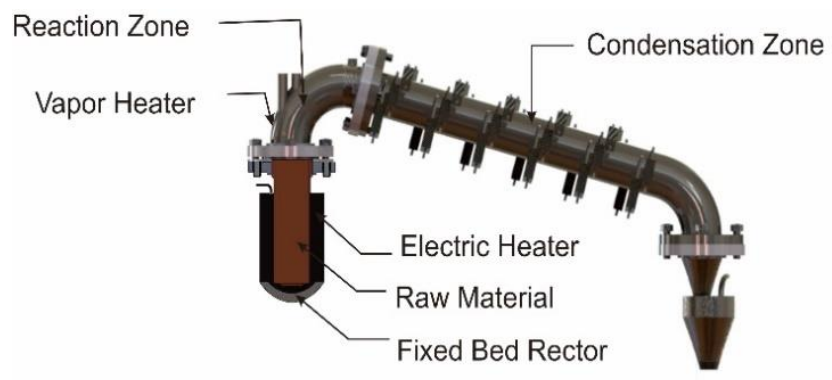

Fig. 2. Schematic process.

equipped with a PID controller to maintain the temperature of the reaction zone wall at a certain value. A temperature sensor was installed on the external wall of the reaction zone to provide a reference temperature to the PID controller. The voltage regulator was connected to the heater in the reaction zone to limit the heat supplied by the heater. Type-K thermocouples were installed at several points of the reactor, reaction zone, input and output cooling water, input and output vapor line of the condenser, liquid product and outlet of the pyrolysis system to record the temperature during the process. There is no sweeping gas injected into the system. Figure 2 shows the schematic process.

Meanwhile Fig. 3 shows the experimental setup for investigating the influence of mesh size feedstock on the liquid yield. All thermocouples and sensor tools were connected to a data-acquisition system, and experimental data were recorded in real-time and stored on a computer.

The positions of the thermocouples used for temperature measurement are as follows: Condenser temperature (T1-T6), Reaction zone wall (T7) Internal reactor wall (T8), Centered on feedstock (T9), Reactor output vapor (T10), Vapor input condenser (T11), External reactor wall (T12), Non-condensable gas (T13).

The condensers were assembled completely by cutting the 3" of the pipe as a shell of condenser, drilling the hole of the shell to insert the heat pipe. The heat pipe was reinforced with $10 \mathrm{~mm}$ of conduit tube and sealed with silicon to avoid vapor leak from the condenser. 


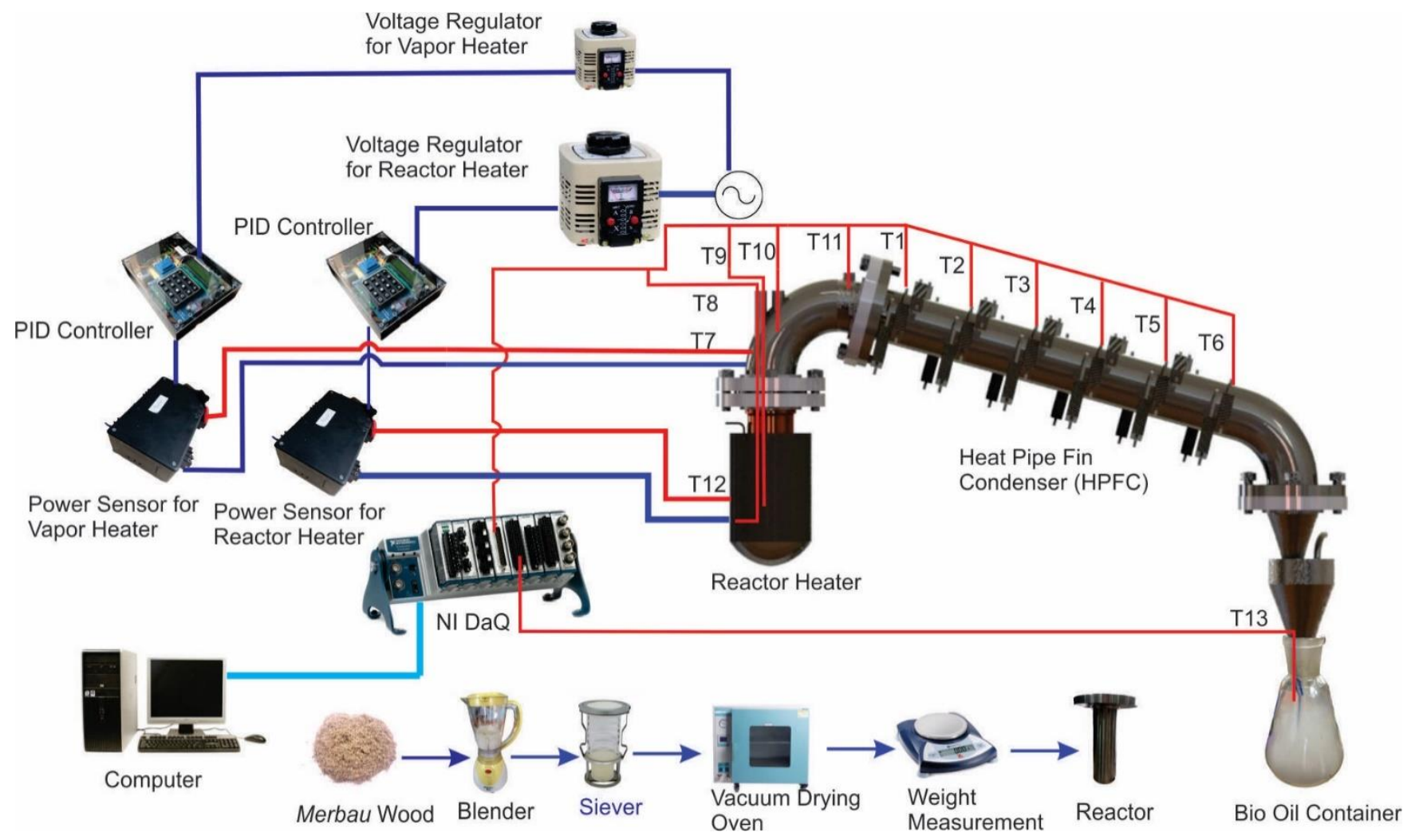

Fig. 3. Experimental setup of the pyrolysis process.

In addition, six thermocouples were placed along the condenser at $3.5 \mathrm{~cm}$ (T1), $15 \mathrm{~cm}$ (T2), $26.5 \mathrm{~cm}$ (T3), $37.5 \mathrm{~cm}$ (T4), $48.5 \mathrm{~cm}$ (T5), and $63.5 \mathrm{~cm}$ (T6), the distance was measured from the flange face of inlet vapor in both condensers respectively. between compare the performance of the heat pipe fin condenser with that of the non-heat pipe condenser, both condensers were constructed with the same shape and specifications.

\subsection{Experimental}

Based on previous research and TGA data, the reaction temperature was maintained at $500^{\circ} \mathrm{C}$ because the maximum liquid yield is produced at temperatures of 400 $600^{\circ} \mathrm{C}$ [25]. A voltage regulator was used to control the supply of power to the heater. 1,500 W power supply units were provided for running the heater. The heating rate was varied from $5^{\circ} \mathrm{C} / \mathrm{min}$ to $12^{\circ} \mathrm{C} / \mathrm{min}$ by varying the vapor temperature. The vapor temperature variations in the reaction zone were as follows: ambient temperature (no vapor heater), $150^{\circ} \mathrm{C}$, and $250^{\circ} \mathrm{C}$. The various temperatures used in the experiment in order to understand the phenomenon of vapor temperature at the reaction zone to the liquid yield. $200 \mathrm{~g}$ of the raw material was placed in the reactor and tested for $3 \mathrm{~h}$. Thermocouples were installed in the reaction zone as well to monitor the temperature changes. The pyrolysis vapor enters the condenser, where it comes into contact with the heat pipe and then condenses into a liquid. The noncondensable gas (NCG) mass balance can be calculated by subtracting the total mass of the raw material from the mass of liquid and char. The liquid yield was measured by weighing the total feedstock along with the mass of the liquid base according to the following equations [26]:

Solid yield $(\%)=\frac{(\text { liquid weight })}{(\text { feed weight })} \times 100 \%$

Solid yield $(\%)=\frac{(\text { solid weight })}{(\text { feed weight })} \times 100 \%$

Ash $($ char yield $)(\%)=$

$100 \%$ - (liquid yield + solid yield $)$

Determining the maximum liquid yield with different particle sizes is our objective in this study. The internal temperature of the heat pipe fin condenser was investigated in order to understand the effectiveness of the heat pipe needed to condense the pyrolysis vapor.

\section{Results and Discussion}

\subsection{Raw Material Properties}

The properties of the Merbau wood raw material were measured and analyzed using TGA and DTA. Figure 4 shows the TGA and DTA curves of Merbau wood. Thermal degradation of the material started at $100^{\circ} \mathrm{C}$; at this temperature, the moisture content of the raw material was released, and the thermal degradation continued. The release of volatile matter and the generation of pyrolysis vapor started at $209^{\circ} \mathrm{C}$; at this temperature, the hemicellulose in the raw material started decomposing (1st 
peak), and this process peaked at $332.3^{\circ} \mathrm{C}$. Subsequently, decomposition of cellulose commenced, and this process peaked at $451.2^{\circ} \mathrm{C}$.

The remaining of the solid residue decomposed at higher temperatures. The range of decomposition temperature of hemicellulose and cellulose was 220 $315^{\circ} \mathrm{C}$ and $315-400^{\circ} \mathrm{C}$, respectively $[27,28]$. High heat flow in the DTA tends to decrease the heating rate of the feedstock [29]. The thermal conductivity of the feedstock was measured to be $0.367 \mathrm{~W} / \mathrm{m} 2 \cdot \mathrm{K}$ with the particle size corresponding to mesh 25 and density of $235 \mathrm{~kg} / \mathrm{m} 3$. The particle size of the raw material affects the heat transfer, including real thermal conductivity. This eventually affects the heating rate of the pyrolysis process.

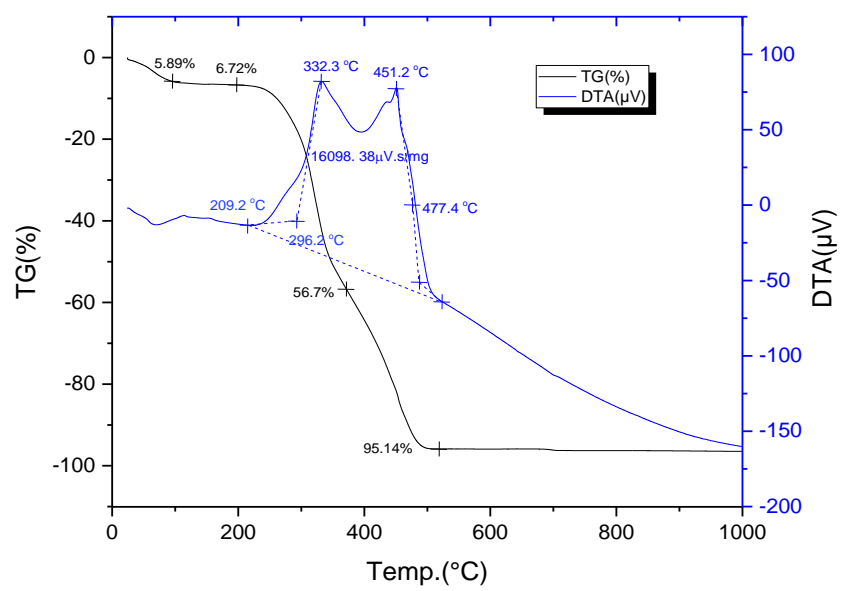

Fig. 4. TGA and DTA graphs of Merbau wood.

\subsection{Effects of Feedstock Particle Size and Reaction Zone Temperature on the Liquid Yield and Properties}

The product yield after the pyrolysis process is summarized in Table 1. The results of previous studies show that varying the power supplied to the reactor's electric heater affects the liquid yield. Supplying a greater amount of power increases the heating rate. However, the increase in the liquid yield with increasing reactor heating rate tapers off after reaching a peak. The TGA/DTA data indicate that the feedstock decomposed at $200-550^{\circ} \mathrm{C}$, and the optimum reaction temperature is $500^{\circ} \mathrm{C}$ [25].

The product yields corresponding to different vapor heater temperatures and wood particle sizes are shown in Fig. 5. In the experiment, we used a 1,500 W electric heater in the reactor to maintain the reactor's temperature at $500^{\circ} \mathrm{C}$. In addition, the vapor heater power was maintained at $500 \mathrm{~W}$ by varying the setting of reaction zone temperature.

The result shows that as the particle size decreased, the liquid yield decreased. The smallest particles reduced the heating rate of feedstock owing to the thermal resistance to surface contact in the weakly endothermic pyrolysis reaction. By contrast, when the particle size was larger (smaller mesh size), a greater amount of liquid was produced. J. Guan et al. conducted an experiment related to the pyrolysis of granular biomass. Their results showed that the larger the particle size, the slower the heat transmission into the particle core in a large endothermic pyrolysis reaction [11]. By contrast, the smaller the particle size, the faster the transmission of heat into the particle core. This means that it is easier to spread heat into the particle core, meaning that the transmission of heat through large particles would be slow. Thus, the pyrolysis process takes longer to generate a liquid, which leads to higher liquid yields.

Table 1. The product yield of the pyrolysis process.

\begin{tabular}{|c|c|c|c|c|c|c|}
\hline \multirow{2}{*}{$\begin{array}{l}\text { Reactor } \\
\text { heater }\end{array}$} & \multirow[b]{2}{*}{ Mesh } & \multirow{2}{*}{$\begin{array}{l}\text { Vapor } \\
\text { heater }\end{array}$} & \multirow{2}{*}{$\begin{array}{l}\text { Heating } \\
\text { rate } \\
\left({ }^{\circ} \mathrm{C} / \mathrm{min}\right)\end{array}$} & \multicolumn{3}{|c|}{ Product yield } \\
\hline & & & & Liquid & NCG & Char \\
\hline \multirow{3}{*}{$1,500 \mathrm{~W}$} & \multirow{3}{*}{10} & $\begin{array}{l}\text { Heater } \\
\text { off }\end{array}$ & 5.685 & 37.0 & 28.5 & 34.5 \\
\hline & & $150^{\circ} \mathrm{C}$ & 14.026 & 40.0 & 28.0 & 32.0 \\
\hline & & $250^{\circ} \mathrm{C}$ & 11.625 & 42.5 & 22.5 & 35.0 \\
\hline \multirow{3}{*}{$1,500 \mathrm{~W}$} & \multirow{3}{*}{25} & $\begin{array}{c}\text { Heater } \\
\text { off }\end{array}$ & 7.512 & 38.0 & 26.5 & 35.5 \\
\hline & & $150^{\circ} \mathrm{C}$ & 5.212 & 39.0 & 28.0 & 33.0 \\
\hline & & $250^{\circ} \mathrm{C}$ & 5.118 & 41.0 & 22.5 & 36.5 \\
\hline \multirow{3}{*}{$1,500 \mathrm{~W}$} & \multirow{3}{*}{30} & $\begin{array}{c}\text { Heater } \\
\text { off }\end{array}$ & 5.421 & 35.0 & 39.5 & 25.5 \\
\hline & & $150^{\circ} \mathrm{C}$ & 5.526 & 35.5 & 39.0 & 25.5 \\
\hline & & $250^{\circ} \mathrm{C}$ & 5.505 & 36.5 & 25.5 & 38.0 \\
\hline
\end{tabular}

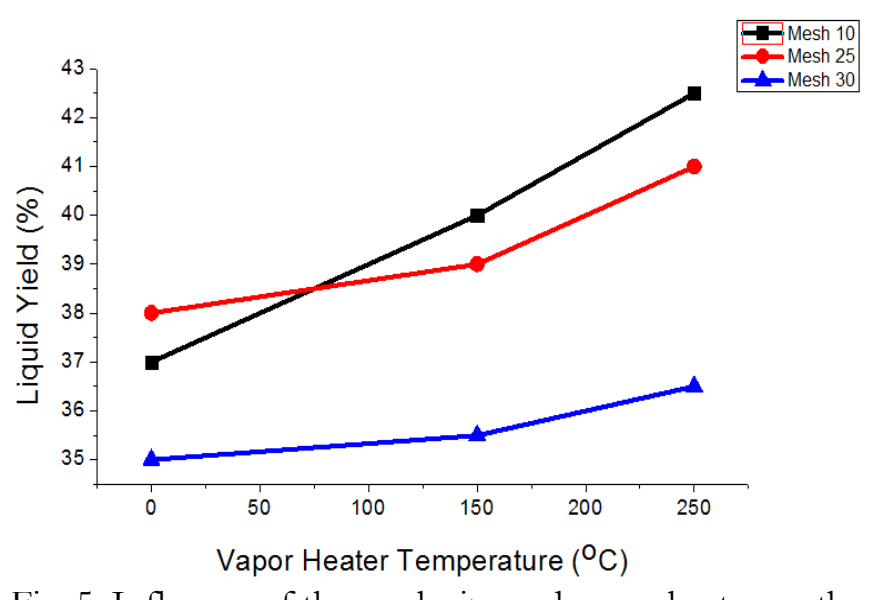

Fig. 5. Influence of the mesh size and vapor heater on the liquid yield.

Figure 6 shows the experimental graph of temperature distribution during the pyrolysis process. The experiments were conducted with three particle sizes, namely, mesh 10 [shown in graphs (a), (b), and (c)], mesh 25 [shown in graphs (d), (e), and (f)], and mesh 30 [shown in graphs (g), (h), and (i)], and the vapor heater temperatures corresponding to graphs (a), (d), and (g); (b), (e), and (f); and (c), (f), (i) are ambient temperature (heater off) $150^{\circ} \mathrm{C}$, and $250^{\circ} \mathrm{C}$, respectively. The temperature distribution of the feedstock shows the highest heating rate for mesh 10 particles with a vapor temperature of $250^{\circ} \mathrm{C}$. The higher heating rate was indicated by the gradient line of feedstock temperature (Fig. 6(c)) compared to the other graph. 


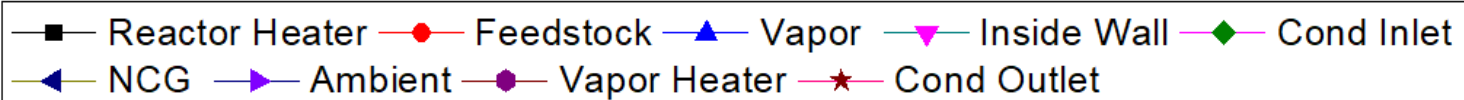

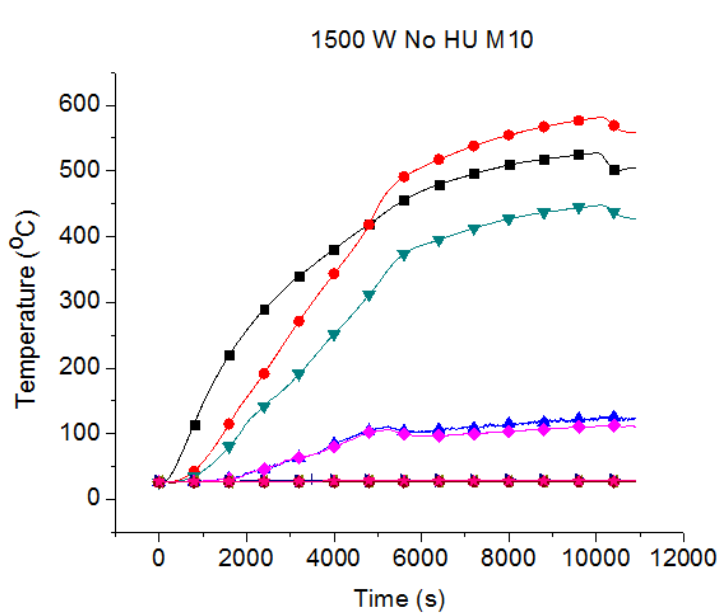

(a)

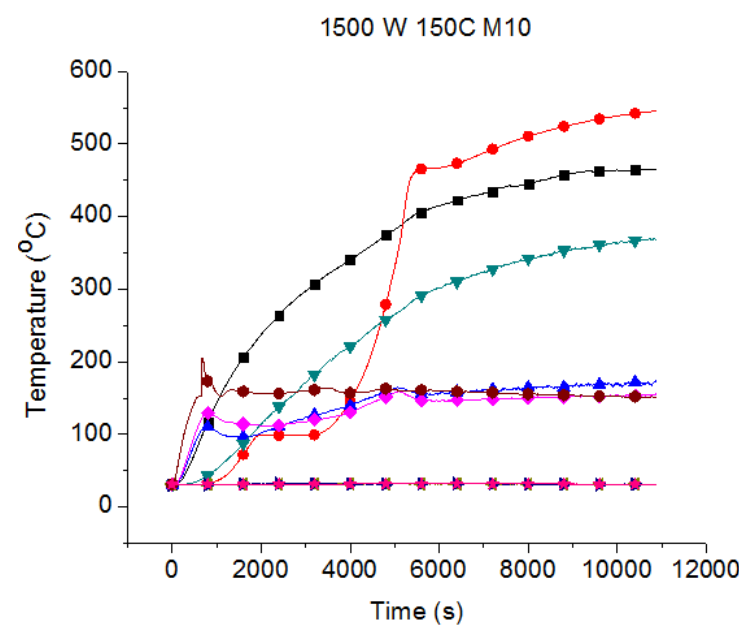

(b)

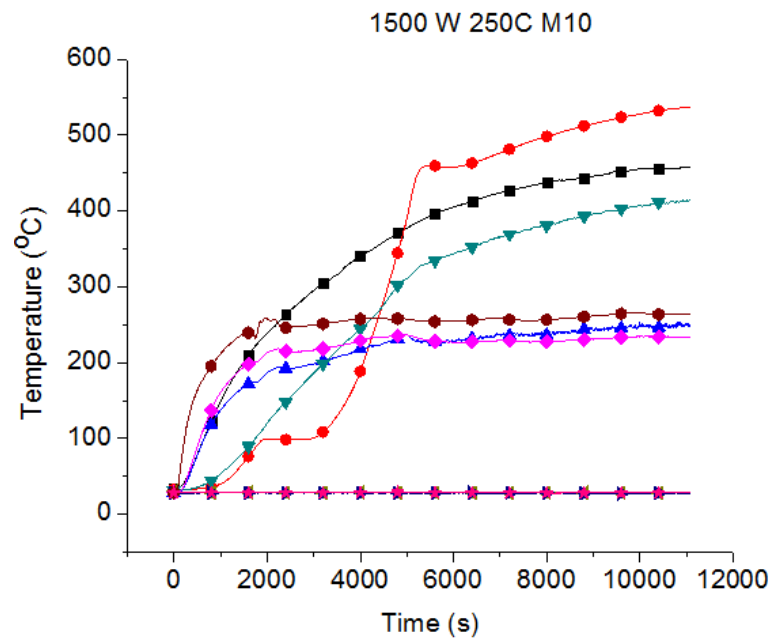

(c)

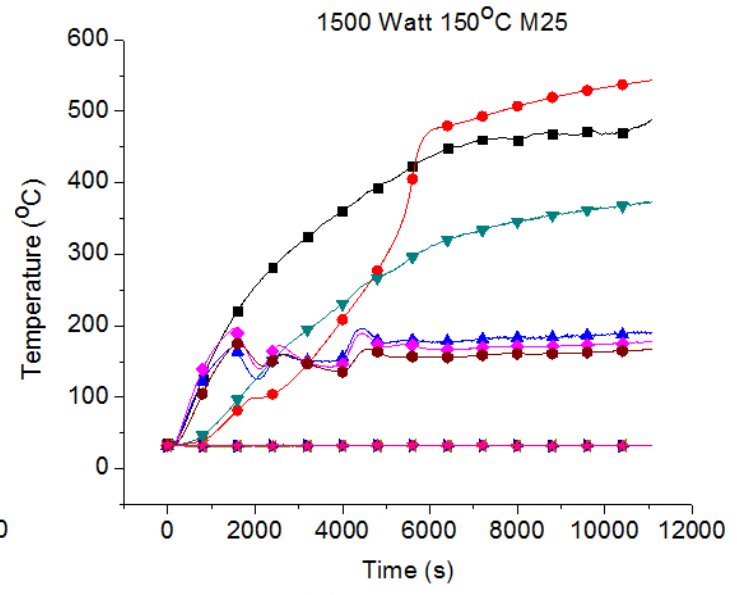

(e)

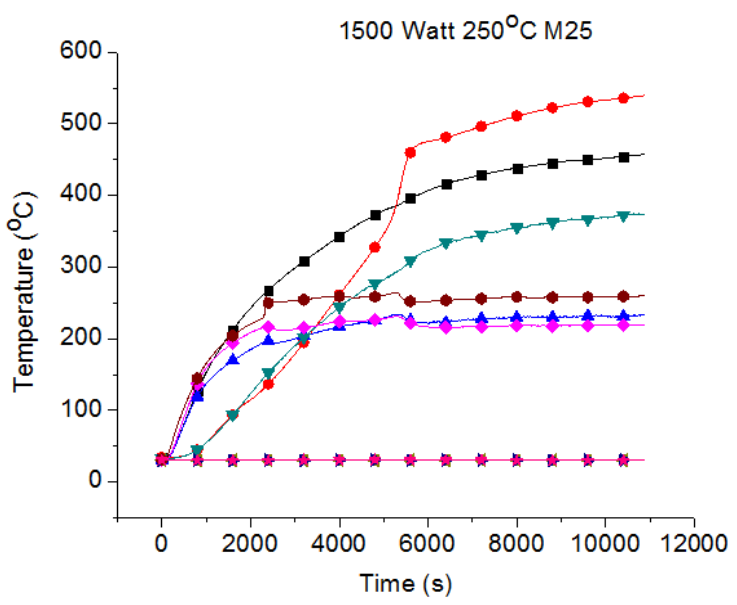

(f) 


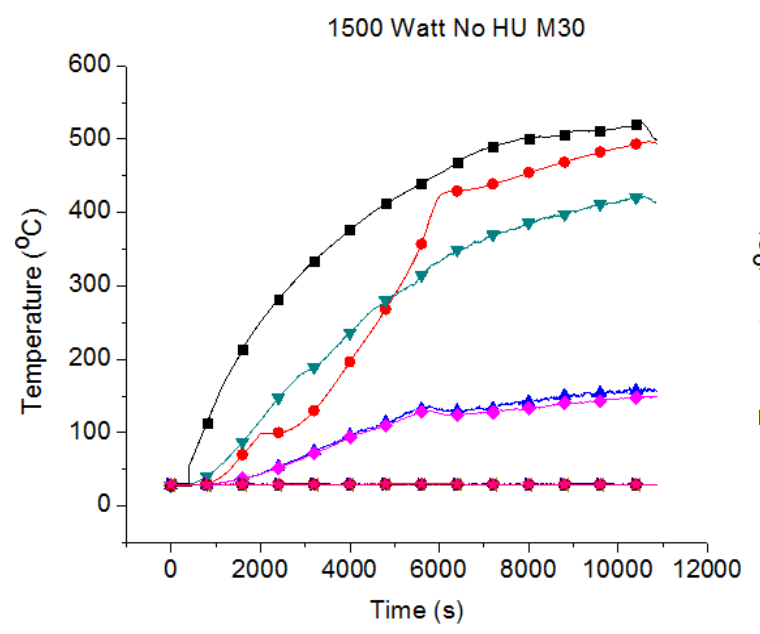

$(\mathrm{g})$

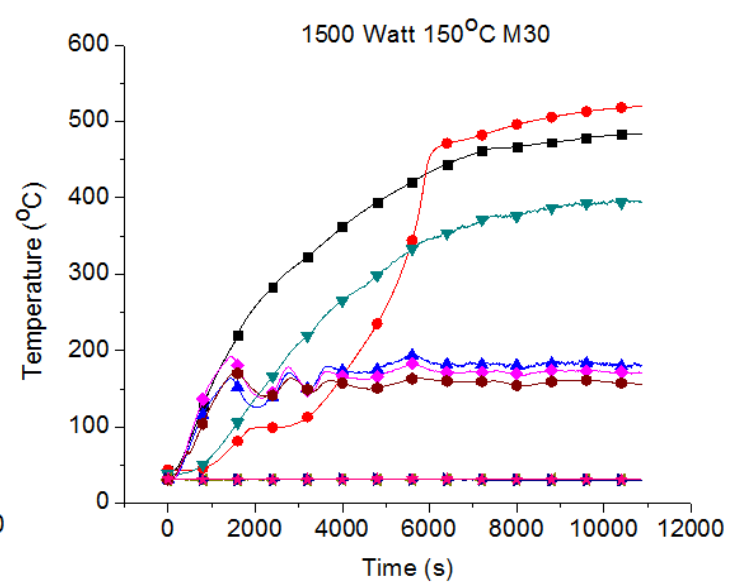

(h)

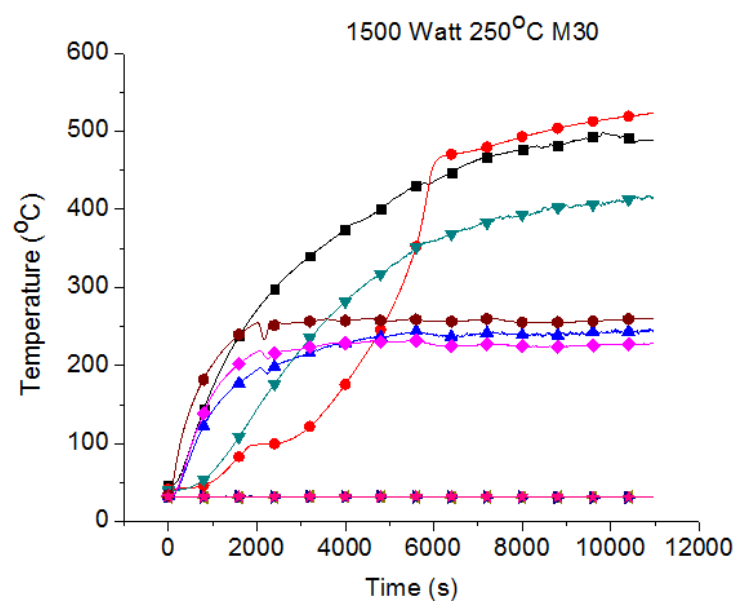

(i)

Fig. 6. Temperature distributions in the pyrolysis process using a heat pipe fin condenser (5a-5i).

The particle size corresponding to mesh 10 has the highest gradient of $14.026^{\circ} \mathrm{C} / \mathrm{min}$, and the corresponding liquid yield was $42.5 \mathrm{wt} . \%$. From the feedstock temperature in the TGA/DTA graphs, at $100^{\circ} \mathrm{C}$, the biomass releases moisture, as indicated by the flat line of feedstock temperature. Then, vapor generation occurs up to temperatures of $500^{\circ} \mathrm{C}$. The heating rate calculation is based on the trend line of feedstock temperature. An exothermic process occurred in this pyrolysis process, considering that the feedstock temperature was higher than the reactor wall temperature. In addition, the reaction temperature also affects the composition of the liquid due to the cracking and decomposition processes that occur on the feedstock.

Meanwhile, the vapor temperatures at the condenser inlet and outlet are shown in graphs 6(a)-6(i) for several variations of input vapor temperature to the condenser according to variations of the vapor temperature in the reaction zone. The condenser outlet temperature remained constant throughout the process.
When the vapor temperature in the reaction zone was higher than $250^{\circ} \mathrm{C}$, the condenser outlet temperature remained low and almost the same as the ambient temperature, which indicates that the heat pipe works and can reduce the vapor temperature and condense the vapor into a liquid.

The $\mathrm{pH}$ of the product decreased as the vapor temperature increased, and the compounds in the liquid influenced its $\mathrm{pH}$. At the highest vapor temperature, the proportion of compounds with high boiling points in the liquid increased. Among the component compounds, water and acids had the lowest boiling points, Meanwhile, the component compound with the high boiling point consist of high heating value [25]. There was no significant distinction in terms of the thermal conductivity and density of the liquid. The $\mathrm{pH}$, thermal conductivity, and density of the liquid are listed in Table 2. 
Table 2. Thermal conductivity, density, and $\mathrm{pH}$ of the liquid.

\begin{tabular}{lcccc}
\hline $\begin{array}{l}\text { Vapor } \\
\text { heater } \\
(500 \mathrm{~W})\end{array}$ & Mesh & $\begin{array}{c}\text { Thermal } \\
\text { conductivity } \\
\left(\mathrm{m} / \mathrm{W}^{\circ} \mathrm{C}\right)\end{array}$ & $\begin{array}{c}\text { Density } \\
\left(\mathrm{g} / \mathrm{cm}^{3}\right)\end{array}$ & $\mathrm{pH}$ \\
\hline $\begin{array}{l}\text { No heater } \\
\text { vapor }\end{array}$ & 0.03 & 1.21 & 2.5 \\
$150^{\circ} \mathrm{C}$ & 10 & 0.03 & 1.28 & 2.4 \\
$250^{\circ} \mathrm{C}$ & & 0.03 & 1.25 & 2.2 \\
\hline $\begin{array}{l}\text { No heater } \\
\text { vapor }\end{array}$ & 0.03 & 1.25 & 2.4 \\
$150^{\circ} \mathrm{C}$ & 25 & 0.03 & 1.32 & 2.2 \\
$250^{\circ} \mathrm{C}$ & & 0.03 & 1.27 & 2.0 \\
\hline $\begin{array}{l}\text { No heater } \\
\text { vapor }\end{array}$ & 0.03 & 1.25 & 2.3 \\
$150^{\circ} \mathrm{C}$ & 30 & 0.03 & 1.24 & 2.2 \\
$250^{\circ} \mathrm{C}$ & & 0.03 & 1.23 & 2.1 \\
\hline
\end{tabular}

3.3. Performance of and Temperature Distribution in Heat Pipe Fin Condensers

Figure 7 and Table 3 show the temperature distribution, and the temperature dropped along with the condenser. Heat pipes can significantly reduce the vapor temperature. A comparison of temperature distribution between the condenser with the heat pipe and that without the heat pipe can be shown in Fig 8. The Temperature of T1 initially at $180^{\circ} \mathrm{C}$ and decrease significantly at $\mathrm{T} 2$ due to the high vapor temperature. There is no significant temperature difference between $\mathrm{T} 1$ and $\mathrm{T} 2$ between the heat pipe and non-heat pipe condenser. At T5, the temperature of the pyrolysis vapor was close to the ambient temperature $\left(28^{\circ} \mathrm{C}\right)$. This means that all heat pipes did not function at their maximum ability. An effective heat pipe performance was observed at T2, T3, and T4. The heat pipes that functioned maximally on the condenser range only up to T4 $(37.5 \mathrm{~cm})$, which means only 18 heat pipes are required to condense the vapor maximally. A comparison of the drop in vapor temperature between the condenser with the heat pipe and that without the heat pipe is shown in Fig. 8.

Pyrolysis with mesh 10 particles and vapor temperature of $250^{\circ} \mathrm{C}$ produced more liquid than in the case of ambient temperature vapor. The yields of a few of the high-boiling-point component compounds in the liquid were higher with the particle size corresponding to mesh 10 and vapor temperature of $250^{\circ} \mathrm{C}$. Some vapors of the high- boiling-point compounds condensed on the reaction- zone wall owing to the low temperature of the wall in the case when the vapor heater was not used [19]. By contrast, the use of the vapor heater maintained the wall temperature at a high level, preventing premature vapor condensation, as indicated by the higher percentage in case of the vapor temperature of $250^{\circ} \mathrm{C}$. The listing of different product yields can be ascribed to the different heating rates, as well as the possibility of the second reaction and vapor deformation owing to high vapor temperatures. In addition to the type of raw material, the heating rate and the vapor temperature influenced the liquid product.

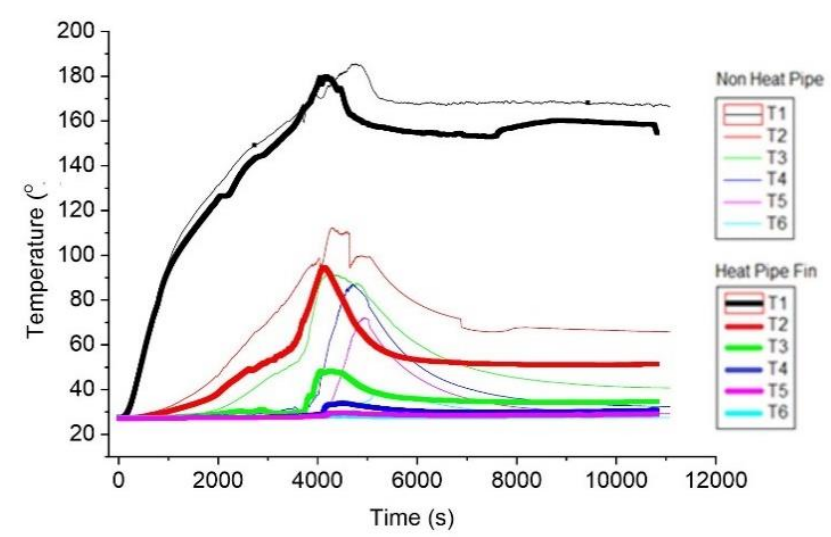

Fig. 7. Temperature distributions in the pyrolysis process using a heat pipe fin condenser.

Table 3. Temperature comparison between condensers with a heat pipe and those without a heat pipe.

\begin{tabular}{cccc}
\hline $\begin{array}{c}\text { Thermocouple } \\
\text { position }\end{array}$ & $\begin{array}{c}\text { Without } \\
\text { heat pipe } \\
\left({ }^{\circ} \mathrm{C}\right)\end{array}$ & $\begin{array}{c}\text { With heat } \\
\text { pipe }\left({ }^{\circ} \mathrm{C}\right)\end{array}$ & Delta $\left({ }^{\circ} \mathrm{C}\right)$ \\
\hline $\mathrm{T}_{1}$ & 185.34 & 179.47 & 5.87 \\
$\mathrm{~T}_{2}$ & 112.05 & 94.39 & 17.66 \\
$\mathrm{~T}_{3}$ & 90.97 & 48.25 & 42.72 \\
$\mathrm{~T}_{4}$ & 86.3 & 33.79 & 52.51 \\
$\mathrm{~T}_{5}$ & 71.58 & 29.44 & 42.14 \\
$\mathrm{~T}_{6}$ & 38.97 & 27.9 & 11.07 \\
\hline
\end{tabular}

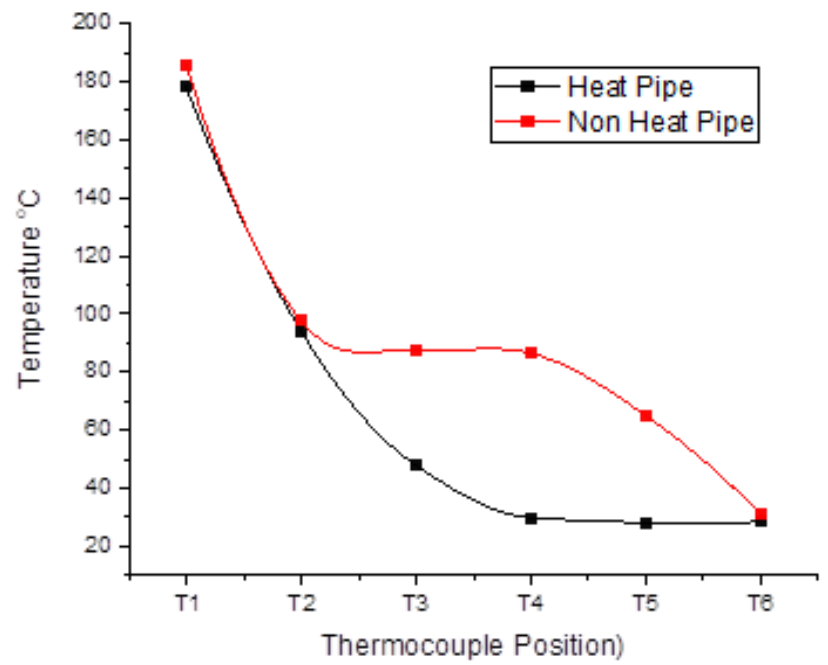

Fig. 8. Temperature drops along with the condenser.

In all experiments conducted herein, aerosol clumps were formed when the feedstock temperature almost crossed the inner wall temperature, and this aerosol disappeared slowly. This aerosol was formed owing to 
the thermal degradation of the feedstock inside the reactor. Although this aerosol was not the same as aerosols in general (which are liquids dispersed in gases), it comprised solid particles of unburned carbon mixed through rising warm water clouds [26].

\section{Conclusions}

The use of a heat pipe with fins in the condenser of a pyrolysis system using Marbau wood as feedstock was investigated, in addition to liquid yields for various combinations of feedstock particle size and pyrolysis vapor temperature. Hence, we arrived at the following conclusions. The smaller the particle size, the lower the liquid yield, and vice versa. With a particle size of $2 \mathrm{~mm}$, we achieved a $6 \%$ higher yield of liquid smoke than that with a particle size of $0.595 \mathrm{~mm}$. The higher the vapor temperature, the higher the liquid yield. An LCS condenser with a heat pipe can significantly decrease the vapor temperature. Therefore, this condenser can be applied in the pyrolysis process to condense vapor into a liquid. The composition of the resulting product changes with the heating rate, vapor temperature, and particle size, and a higher vapor temperature increases the yield of high-boiling-point compounds in the final product. The vapor temperature influenced the liquid, eventually, it affects the $\mathrm{pH}$ of the liquid. $\mathrm{pH}$ of the liquid product decreased with increasing vapor temperature.

\section{Acknowledgment}

The authors wanted to express gratitude to DRPM Universitas Indonesia and Kemenristek Dikti for funding this research through the "Hibah PTUPT" scheme.

\section{References}

[1] R. Azargohar, K. L. Jacobson, E. E. Powell, and A. K. Dalai, "Evaluation of properties of fast pyrolysis products obtained, from Canadian waste biomass," Journal of Analytical and Applied Pyrolysis, vol. 104, pp. 330-340, 2013.

[2] A. K. Agarwal, "Biofuels (alcohols and biodiesel) applications as fuels for internal combustion engines," Progress in Energy and Combustion Science, vol. 33, no. 3, pp. 233-271, 2007.

[3] E. Suñen, B. Fernandez-Galian, and C. Aristimuño, "Antibacterial activity of smoke wood condensates against Aeromonas hydrophila, Yersinia enterocolitica and Listeria monocytogenes at low temperature," Food Microbiology, vol. 18, no. 4, pp. 387-393, 2001.

[4] P. J. Milly, R. T. Toledo, and S. Ramakrishnan, "Determination of minimum inhibitory concentrations of liquid smoke fractions," Journal of Food Science, vol. 70, no. 1, 2005.
[5] J. Lehto, A. Oasmaa, Y. Solantausta, M. Kytö, and D. Chiaramonti, "Review of fuel oil quality and combustion of fast pyrolysis bio-oils from lignocellulosic biomass," Applied Energy, vol. 116, pp. 178-190, 2014.

[6] P. Rout, M. Naik, S. Naik, V. V. Goud, L. Das, and A. K. Dalai, "Supercritical $\mathrm{CO}_{2}$ fractionation of bio-oil produced from mixed biomass of wheat and wood sawdust," Energy \& Fuels, vol. 23, no. 12, pp. 6181-6188, 2009.

[7] D. A. Laird, R. C. Brown, J. E. Amonette, and J. Lehmann, "Review of the pyrolysis platform for coproducing bio-oil and biochar," Biofuels, Bioproducts and Biorefining, vol. 3, no. 5, pp. 547-562, 2009.

[8] B. Freel and R. G. Graham, "Bio-oil preservatives," U.S. Patent 6,485,841, Nov. 26, 2002.

[9] J. M. Lingbeck, P. Cordero, C. A. O'Bryan, M. G. Johnson, S. C. Ricke, and P. G. Crandall, "Functionality of liquid smoke as an all-natural antimicrobial in food preservation," Meat Science, vol. 97, no. 2, pp. 197-206, 2014.

[10] N. A. Abdullah, N. Putra, R. N. Ningrum, I. I. Hakim, and R. A.Koestoer, "The effect of heating rate and optimum temperature distribution on the maximum liquid produced in a non-sweep gas fixed-bed pyrolysis reactor," University of Indonesia, 2019.

[11] J. Guan, G. Qi, and P. Dong, “A granular-biomass high temperature pyrolysis model based on the Darcy flow," Frontiers of Earth Science, vol. 9, no. 1, pp. 114-124, 2015.

[12] M. I. Jahirul, M. G. Rasul, A. A. Chowdhury, and N. Ashwath, "Biofuels production through biomass pyrolysis-A technological review," Energies, vol. 5, no. 12, pp. 4952-5001, 2012.

[13] J. Akhtar and N. S. Amin, "A review on operating parameters for optimum liquid oil yield in biomass pyrolysis," Renewable and Sustainable Energy Reviews, vol. 16, no. 7, pp. 5101-5109, 2012.

[14] N. A. Abdullah, N. Putra, I. I. Hakim, and R. A. Koestoer, "A review of improvements to the liquid collection system used in the pyrolysis process for producing liquid smoke," International Journal of Technology, vol. 8, no. 7, pp. 1197-1206, 2017.

[15] F. Abnisa and W. M. A. Wan Daud, "A review on co-pyrolysis of biomass: An optional technique to obtain a high-grade pyrolysis oil," Energy Conversion and Management, vol. 87, pp. 71-85, 2014.

[16] J. G. Hwang, H. S. Choi, and H. C. Park, "Condensation performance of two different heat exchangers for collecting pyrolyzed oil," in The 26th Annual Conference of JSMCWM, 2015, p. 592.

[17] N. A. Abdullah, A. Novianti, I. I. Hakim, N. Putra, and R. A. Koestoer, "Influence of temperature on conversion of plastics waste (polystyrene) to liquid oil using pyrolysis process," in IOP Conference Series: 
Earth and Environmental Science, IOP Publishing, 2018, vol. 105, no. 1, p. 012033.

[18] A. Hasnan, N. Putra, W. N. Septiadi, B. Ariantara, and N. A. Abdullah, "Vapor chamber utilization for rapid cooling in the conventional plastic injection molding process," International Journal of Technology, vol. 8, no. 4, pp. 690-697, 2017.

[19] N. A. Abdullah, J. Tila, I. I. Hakim, and N. S. D. J. I. J. o. T. Putra, "An experimental study of the vapor temperature in the reaction zone for producing liquid from camphor wood in a nonsweeping gas fixed-bed pyrolysis reactor," International Journal of Technology, vol. 9, no. 6, pp. 1236-1245, 2018.

[20] M. Mahdavi, S. Tiari, S. De Schampheleire, and S. Qiu, "Experimental study of the thermal characteristics of a heat pipe," Experimental Thermal and Fluid Science, vol. 93, pp. 292-304, 2018.

[21] P. Kim, S. Weaver, and N. Labbé, "Effect of sweeping gas flow rates on temperature-controlled multistage condensation of pyrolysis vapors in an auger intermediate pyrolysis system," Journal of Analytical and Applied Pyrolysis, vol. 118, pp. 325334, 2016.
[22] T. Chen, C. Deng, and R. Liu, "Effect of selective condensation on the characterization of bio-oil from pine sawdust fast pyrolysis using a fluidizedbed reactor," Energy \& Fuels, vol. 24, no. 12, pp. 6616-6623, 2010.

[23] M. Rasul and M. I. Jahirul, "Recent developments in biomass pyrolysis for bio-fuel production: Its potential for commercial applications," Central Queensland University, Centre for Plant and Water Science, Faculty of Sciences, Engineering and Health, 2012.

[24] J. Cai et al., "Review of physicochemical properties and analytical characterization of lignocellulosic biomass," Renewable and Sustainable Energy Reviews, vol. 76, pp. 309-322, 2017.

[25] T. Schulzke, S. Conrad, and J. Westermeyer, "Fractionation of flash pyrolysis condensates by staged condensation," Biomass and Bioenergy, vol. 95, pp. 287-295, 2016.

[26] J. Fang, A. Leavey, and P. Biswas, "Controlled studies on aerosol formation during biomass pyrolysis in a flat flame reactor," Fuel, vol. 116, pp. 350-357, 2014.

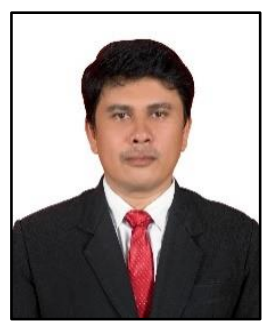

Nasruddin A. Abdullah was born in Aceh, Indonesia In 1974. He received a Bachelor's degree in fluid mechanics mechanical engineering from Malikulsaleh University in 1999, and a Master's degree also in fluid mechanics and thermofluid, mechanical engineering from USU Medan in 2013, and a Ph.D. degree in Heat transfer and thermofluid Mechanical Engineering from Universitas Indonesia in 2019.

From 2015 to 2019 was a Ph.D. student and he is a member of Applied Heat Transfer Research Group, Mechanical Engineering Universitas Indonesia. Since 2019, He has been a lecturer in Mechanical Engineering Universitas Samudra as an Assistant Professor. He is the Author and CoAuthor of nine papers, which has Scopus indexed and more than seven national and international conference proceedings, he also has one invention. His research interest includes pyrolysis, heat pipe and phase change materials.

Dr. Nasruddin was a receipt of the best presentation award in International Meeting on Advances in Thermofluids 2017.

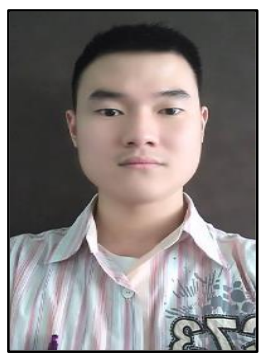

Jordy Tila was born in Jakarta, Indonesia In 1996. He finished a bachelor's degree in Mechanical Engineering from Universitas Indonesia in 2018.

From 2017 to 2018 he is a research assistant of heat transfer laboratory, Mechanical Engineering Universitas Indonesia. Since 2019, He has two publications in Scopus indexed. 


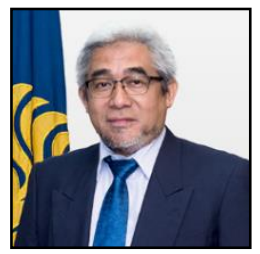

Imansyah Ibnu Hakim was born in Jakarta, Indonesia, in 1968. He received the Bachelor's degree in mechanical engineering from Faculty of Engineering, Universitas Indonesia, Depok, in 1993, Master degree in advance energy engineering science from Interdisciplinary Graduate School of Engineering Sciences, Kyushu University, Japan, in 2000, and the Doctor degree in mechanical engineering from Faculty of Engineering, Universitas Indonesia, Depok in 2012.

From 2000 to 2002, He was a teaching assistant in the Department of Advance Energy Engineering Science from Interdisciplinary Graduate School of Engineering Sciences, Kyushu University. He is an Associate Dean for Cooperation and Venture, Faculty of Engineering, Universitas Indonesia. Since 2004, He has been a lecturer in the Mechanical Engineering Department, Faculty of Engineering, Universitas Indonesia. He has more than 40 publications in the reputable journal and has published the paper in many journals majoring in thermophoresis, heat pipe, nanofluids, thermoelectric, phase-change material, and liquid smoke (pyrolysis).

Dr. Ir. Imansyah was a member of The Institution of Engineer Indonesia as Insinyur Profesional Madya (IPM) and also holds two patents about thermal precipitator for collecting smoke particulates and thermoelectric-based multifunctional heaters or coolers.

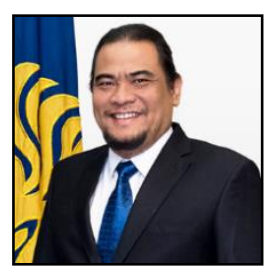

Nandy Setiadi Djaya Putra was born in Palembang, Indonesia, in 1970. He received a Bachelor's degree in mechanical engineering from Universitas Indonesia in 1994, Master and Ph.D. in heat transfer in dispersed material mechanical engineering from The University of Federal Armed Forces, Hamburg, Germany, in 2002 and received the professor in 2009.

From 1998 to 2002, He was a research member of The University of Federal Armed Forces, Hamburg, during Ph.D. study and published more than five papers in the reputable journal. Since 2002, He has been a lecturer in the Mechanical Engineering Department, Faculty of Engineering, Universitas Indonesia, and from 2009 as a professor. He is a Vice Dean for Resources, Venture, and General Administration in Faculty of Engineering, Universitas Indonesia. He is a leader in Applied heat transfer research group and evaporative cooling. He was leading the research with Heat Pipe Nanofluids Thermoelectric PCM and Liquid Smoke (pyrolysis). He has more than 100 publications in the reputable journal and has published the paper in many journals majoring in heat pipe, nanofluids, thermoelectric, phase-change material and liquid smoke (pyrolysis). He is the author of six books, which has been published as the teaching book. He also has three inventions and one patent. He has been involved as reviewer in some Journal.

Prof. Dr.-Ing Nandy was a recipient of 5th The Best Researcher in Universitas Indonesia in 2011, Best Paper Award 6th International Meeting on Advanced Thermofluid 2013, the most prospective innovation researcher award from the ministry of research and technology (2015) and more than five award from Universitas Indonesia and government.

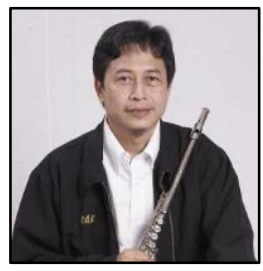

Raldi Artono Koestoer was born in Jakarta, Indonesia In 1954. He received a Bachelor's degree in Mechanical Engineering from Universitas Indonesia in 1978, a Master's degree in Ecole Nationale Superieure de Mecanique et Aeronautique from Poitiers - France. in 1981, and a Ph.D. degree in Docteur-Ingeniueur in Heat Transfer from Universite de Paris XII Val de Marne, FRANCE in 1985.

He has published more than 40 papers as author and co-author in the journal, and more than 20 international conference proceedings, He has been a lecturer in Mechanical Engineering Universitas Indonesia as a Professor. he also has two inventions. His research interest includes pyrolysis, heat pipe, phase change materials, evaporative cooling, and power plan. Dr. Koestoer was a recipient seven award from government and from university 